\title{
DEPRESSION AND SOCIAL SUPPORT IN OLD AGE
}

\author{
Ana Filipa Pimentel ${ }^{1}$, Rosa Marina Afonso ${ }^{2}$ (rmafonso@ubi.pt) \& Henrique Pereira ${ }^{3}$
}

1, 2, 3, University of Beira Interior, Covilhã, Portugal; 2 Research Unit of Education on Adults and the Elderly (UNIFAI), Institute of Biomedical Sciences - University of Porto; 3, Research unit in Psychology and Health (UIPES), ISPA - University Institute,

\begin{abstract}
There is a high incidence of depression in old age, being its prevalence higher in institutionalized elderly, which is sometimes related to the threat or actual rupture of affective bonds and support. This research aims at assessing depressive symptoms and satisfaction with social support, and their association, in institutionalized elderly. A cross-sectional and descriptive design was developed. A socio-demographic questionnaire, the Geriatric Depression Scale and the Satisfaction with Social Support Scale were applied to 117 institutionalized Portuguese elderly, older than 65 years. The results indicated a high incidence of depression in the institutionalized elderly (73.5\%). The level of depression tends to be higher in the elderly over 75 years old $(t(115)=-2.115$, $p=.037, M=17.88, S D=8.17$ ) and who did not enter the nursing home by their own initiative $(t(115)=-2.586, p=.011, M=19.05, S D=7.64)$. The average satisfaction with social support was high $(M=58.59, S D=6.93)$, the older female participants presented the highest satisfaction rate with social support $(t(115)=-2.456, p=.016, M=59.49, S D=6.01)$. The results obtained also report a significant negative correlation $(r=-.36, p<.01)$ between the levels of depressive symptoms and the levels of satisfaction with social support. The results suggest that social support can mitigate depressive symptoms in the elderly.
\end{abstract}

Keywords- Aging, Depression, Social Support, Institutionalization.

\section{DEPRESSÃO E SUPORTE SOCIAL NA VELHICE}

RESUMO: Existe uma elevada incidência de depressão na velhice, sendo a prevalência maior em pessoas idosos institucionalizadas, o que, poderá estar relacionado com a ameaça ou rutura de laços afetivos e de suporte. Este estudo tem como objetivo avaliar os sintomas depressivos, a satisfação com o apoio social e a relação entre estas variáveis, em idosos institucionalizados. Foi desenvolvido um estudo transversal e descritivo. Foi aplicado um questionário sócio-demográfico, a Escala de Depressão Geriátrica e a escala de satisfação com o apoio social a 117 pessoas idosas portuguesas, com mais de 65 anos e que residiam em instituições. Os resultados indicaram uma alta incidência de depressão em idosos institucionalizados (73,5\%). O nível de depressão tende a ser maior nos idosos com mais de 75 anos $(t(115)=-2,11, p=0,03, M=17,88, D P=8,17)$ e nos idosos que não ingressaram no lar por iniciativa própria $(t(115)=-2,58, p=0,01, M=19,05, D P=7,64)$. A média de satisfação com o apoio social foi elevada $(M=58,59, D P=6,93)$, sendo as participantes mais velhas do sexo feminino as que apresentaram a maior taxa de satisfação com o suporte social $(t(115)=-2,45, p=0,01, M=59,49, D P=6,01)$. Os resultados obtidos indicam, igualmente, uma correlação negativa significativa $(r=-0,36$, $p<0,01)$ entre a sintomatologia depressiva e os níveis de satisfação com o suporte social. Os resultados sugerem que o apoio social pode atenuar os sintomas depressivos em idosos.

Palavras-Chave- Velhice, Depressão, Suporte Social, Institucionalização. 
Recebido em 12 de Março de 2012/ Aceite em 10 de Novembro de 2012

Depression appears to be the most common psychiatric illness in old age, followed by dementia (e.g., Blazer, 2003; Carrasco, Ortiz, \& Ballesteros, 2002, Norton et al. 2008; Oliveira Santos, Cruvinel \& Neri 2006; Paradela, Veras \& Lawrence, 2005; Scazufca, Mehta \& Almeida, 2002; Stella, Gobbi, Corazza \& Costa, 2002). This psychopathology is frequently misdiagnosed, or not diagnosed, due to the co-morbidity with other diseases (CEIN, 2001; Oliveira, 2005; Veríssimo, 2006), such as dementia, somatization, poor response to antidepressant medication, exacerbation of complaints associated with high levels of anxiety (Garcia et al., 2006, Oliveira et al., 2006).

The non-recognition of depression in old age has several consequences, including: loss of quality of life in the elderly and their families (Kendall \& Warman, 1996; Palarea et al. 2002; Veríssimo, 2006), poor prognosis (Peter, 2003), cognitive decline (Franch, 2002, Strain, Philip \& Blandford, 2006), increased risk of suicide (Costa, 2005; Roth, 2000) and mortality (Palar et al., 2002), and decreased physical capacity (Abas et al., 2002; Irigaray \& Schneider, 2007). On the one hand, these consequences make taking care of the elderly difficult, often leading to a greater need for formal care and their institutionalization. On the other, the elderly that reside in nursing homes appear to be those who present the more pronounced depressive symptoms in old age (Mazza \& Lefèvre, 2004). However, studies are not consensual (Vieira, 1996).

Depression, especially when institutionalization occurs, is often related to the threat or to the actual rupture of affective bonds and support (Fernandes, 2002). Social support is the existence or availability of people who care, appreciate and whom one can trust (Sarason, Levine, Basham \& Sarason, 1983). In other words, it refers to the resources available to the subject, in response to a request for help (Dunst \& Trivette, 1990). In old age, social support comes mainly from the family (Buil \& Espino, 1999; McKevitt, Baldock, Hadlow, Moriarty \& Butt, 2005, Paul, 1994) and friends (Paul \& Fonseca, 2001; McKevitt et al. 2005; Salovey, Detweiler, Steward, \& Rothman, 2000).

The relationship between wellbeing and the maintenance of support systems through life (Ramos, 2002; Roure, Reig \& Vida, 2002) suggests that social support can have mediating effects on health protection, working as "buffer" for stress. Thus, a high degree of social support is associated with a lower risk for severe depressive symptoms and a better prognosis for recovery from depression, in the elderly (Balaswamy, Richardson \& Price, 2004; Carrasco et al., 2002; Glass, Leon, Bassuk \& Berkman, 2006; House \& Umberson, 1988, Cockerham, 1991, Ramos, 2002; Skarsater, Langius, Agren, Haggstrom \& Dencker, 2005).

Thus, this study has the following objectives: i) to assess depressive symptoms in institutionalized elderly; ii) to assess satisfaction with social support in institutionalized elderly; iii) to determine whether there are differences in the depressive symptoms between gender, age, marital status, education, reason for institutionalization, admission on their own initiative and length of the stay; iv) to ascertain whether there are differences in the satisfaction with social support, between different genders, ages, marital statuses, education levels, reasons for institutionalization, admission on their own initiative and length of the stay; 
and, v) to analyze the relation between depressive symptoms and satisfaction with social support in institutionalized elderly, from the municipality of Sátão.

\section{METHOD}

\section{Participants}

A total 117 subjects living in nursing homes, aged between 65 and 101 years $(M=82.23$; $S D=7.85$ ), participated in the study. The socio-demographic characteristics of the sample are summarized in Table 1.

Table 1

Sociodemographic characteristics of the sample $(N=117)$

\begin{tabular}{|c|c|c|c|}
\hline & & Frequency & Percentage \\
\hline \multirow{2}{*}{ Gender } & Male & 30 & 25.6 \\
\hline & Female & 87 & 74.4 \\
\hline \multirow{2}{*}{ Age } & $65-74$ years & 20 & 17.1 \\
\hline & 75- 101 years & 97 & 82.9 \\
\hline \multirow{4}{*}{ Marital Status } & Single & 23 & 19.7 \\
\hline & Divorced & 6 & 5.1 \\
\hline & Married & 17 & 14.5 \\
\hline & Widow & 71 & 60.7 \\
\hline \multirow{6}{*}{ Schooling } & Cannot read/write & 57 & 48.7 \\
\hline & $1^{\text {st }}-4^{\text {th }}$ grade & 51 & 43.6 \\
\hline & $5^{\text {th }}-6^{\text {th }}$ grade & 5 & 4.3 \\
\hline & $7^{\text {th }}-9^{\text {th }}$ grade & 2 & 1.7 \\
\hline & $10^{\text {th }}-12^{\text {th }}$ grade & 1 & .9 \\
\hline & University level & 1 & .9 \\
\hline \multirow{7}{*}{$\begin{array}{l}\text { Motive for } \\
\text { admission }\end{array}$} & Lived alone & & \\
\hline & Difficulty in taking care & 36 & 30.8 \\
\hline & $\begin{array}{l}\text { of himself } \\
\text { Unavailability of the }\end{array}$ & 39 & 33.3 \\
\hline & children to provide & 15 & 12.8 \\
\hline & special care & 14 & 12.0 \\
\hline & $\begin{array}{l}\text { The spouse needs } \\
\text { special care }\end{array}$ & 10 & 8.5 \\
\hline & $\begin{array}{l}\text { Without family/children } \\
\text { Preference for living in } \\
\text { a nursing home }\end{array}$ & 3 & 2.6 \\
\hline \multirow{2}{*}{$\begin{array}{l}\text { Own initiative in } \\
\text { admission }\end{array}$} & Yes & 58 & 49.6 \\
\hline & No & 59 & 50.4 \\
\hline \multirow{4}{*}{$\begin{array}{l}\text { Institutionalization } \\
\text { duration }\end{array}$} & 1 Month - 6 Months & 16 & 13.7 \\
\hline & 7 Months - 1 Year & 24 & 20.5 \\
\hline & 2 Years - 10 Years & 60 & 51.3 \\
\hline & 11 Years - 20 Years & 17 & 14.5 \\
\hline
\end{tabular}

Procedure 
Firstly, the instruments were selected and the authorizations for their application were obtained. The nursing homes were then contacted in order to present the study, and invite them to participate. After the institutions' permissions and the participants' informed consent were acquired, the data was collected through the questionnaires. These were applied in individual interviews, performed by the researcher, given the characteristics of the study population.

\section{Materials}

Socio-demographic Questionnaire - As part of this study, a questionnaire was developed to assess socio-demographic variables: age, gender, education, marital status, reason for institutionalization, admission by own initiative, and duration of the stay.

Geriatric Depression Scale (GDS- 30 items) (Yesavage, Brink, Rose, Lum, Huang, Adey \& Leirer, 1983; Portuguese version by Barreto, 2003)

The Geriatric Depression Scale (GDS) is a self-report screening scale for depression, using a dichotomous response scale, where the elderly respond according to how they felt in the two previous weeks (Martin, Port \& Mellado, 2002). The thirty GDS items assess mood, cognitive complaints and social behavior, however, this scale does not include somatic items (Spar \& Rue, 1998). According to Martin et al. (2002) and the Group for the Study of Brain Aging and Dementia (Barreto, 2003) results between 0 and 10 points are considered normal (i.e. without depression), between 11 and 20 with mild depression, and between 21 and 30 points from moderate to severe depression.

In the present study, the Cronbach's alpha was .93, which is considered excellent according to DeVellis (1991), thereby indicating a high internal consistency and good reliability of the questionnaire. Satisfaction with Social Support Scale (SSSS) (Ribeiro, 1999) -This instrument assesses the level of satisfaction with the perceived support, or with the elements that are part of the relational networks (Siqueira, 2008).

The SSSS is a self-completion scale where the subject expresses his/her level of agreement with fifteen statements. This scale has four factors: satisfaction with friends, intimacy, satisfaction with family, and social activities (Ribeiro, 1999). The total score can vary between 15 and 75 (a score between 51 and 75 corresponds to a high social support, between 26 and 50 to an average social support, and up to 25 to a low social support) (Baptist, Baptist \& Torres, 2006; Ribeiro, 1999).

The internal consistency of the Total-SSSS in this study was $\alpha=.73$, which according to the DeVellis' (1991) criteria is good. Regarding the individual factors, the first factor (satisfaction with friends) presented a good internal consistency $(\alpha=.72)$; the second factor (intimacy) $\alpha=.43$, which is considered unacceptable; the third factor (satisfaction with family) $\alpha=.87$, which is very good; and the fourth factor (social activities) presented an unacceptable internal consistency, $\alpha=37$. Thus, the second and the fourth factors were not analyzed due to unacceptable internal consistency values.

\section{Data analyses}

The data treatment and analysis was performed using the Statistical Package for Social Sciences, version 17.0 (SPSS, An IBM Company, Chicago, IL). 
Descriptive statistics were performed and the internal consistency of the instruments was assessed through Cronbach's alpha. The normality and homogeneity were assessed using the Kolmogorov-Smirnov test. Given the study's variables presented a normal distribution, we used the Student's T-test and the Analysis of Variance (ANOVA). We also performed correlation analysis, using the Pearson's correlation coefficient.

\section{RESULTS}

The GDS results indicate that the mean for the overall scale was 17.16 ( $S D=8.16)$, with a response range between 0 and 30 . We observed that $73.5 \%$ of subjects presented geriatric depression, of these $38.5 \%$ presented mild symptoms and $35 \%$ severe depressive symptoms. Furthermore, $26.5 \%$ of the sample did not present geriatric depression.

Regarding the comparison of depressive symptoms' means between genders, no statistically significant differences were found $(t(115)=-.26, p=.80)$. Concerning age, statistically significant differences were found regarding depression $(t(115)=-2.12, p=.04)$. The results indicate that the elderly aged over 75 years present higher rates of major depressive symptomatology $(M=17.88, S D=8.17)$ than those aged between 65 and 74 years $(M=13.70$; $S D=7.34)$. Moreover, statistically significant differences $(t(115)=-2.59, p=.01)$ were found between subjects who took, and did not take, the initiative in the admission to the nursing homes. Thus, the elderly who did not take the initiative to go to a nursing home presented a higher mean level of depression $(M=19.05, S D=7.64)$ than those who were admitted to nursing homes on their own initiative $(M=15.24, S D=8.29)$ (see Table 2).

Table 2

Results for the comparison of depressive symptoms' mean levels between gender, age, and initiative in admission $(N=117)$

\begin{tabular}{|c|c|c|c|c|c|c|}
\hline & & & $M$ & $S D$ & $D f$ & $t$ \\
\hline \multirow{2}{*}{ Gender } & Male & 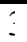 & 16.83 & 9.34 & \multirow{2}{*}{$11 \leqslant$} & \multirow{2}{*}{-.26} \\
\hline & Female & ؛ & 17.28 & 7.77 & & \\
\hline \multirow{2}{*}{ Age } & $65-74$ years & 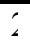 & 13.70 & 7.34 & \multirow{2}{*}{$11:$} & \multirow{2}{*}{$-2,12 *$} \\
\hline & $75-101$ years & $!$ & 17.88 & 8.17 & & \\
\hline \multirow{2}{*}{$\begin{array}{l}\text { Own initiative in } \\
\text { admission }\end{array}$} & Yes & & 15.24 & 8.29 & \multirow{2}{*}{11 ؛ } & \multirow{2}{*}{$-2.59 *$} \\
\hline & No & : & 19.05 & 7.64 & & \\
\hline
\end{tabular}

Note: $*<<0.05 ; * * p<0.01 ; * * * p<0.001$.

No statistically significant differences concerning depression were observed between individuals with different marital statuses $(F(3,113)=.44, p=.73)$, education $(F(5,111)=1.36$, $p=.24)$, motive for admission $(F(5,111)=1.02, p=.41)$, and length of the stay at the nursing home $(F(3,113)=2.65, p=.05)($ see Table 3$)$.

Table 3 
Results for the comparison of depressive symptoms' mean levels and marital status, schooling, reason for admission and length of institutionalization $(N=117)$

\begin{tabular}{|c|c|c|c|c|c|c|}
\hline & & $r$ & $M$ & $S D$ & $D f(B ; W$ & $F$ \\
\hline \multirow{4}{*}{ Marital Status } & Single & 2 & 16.52 & 8.86 & \multirow{4}{*}{3,113} & \multirow{4}{*}{.44} \\
\hline & Divorced & $t$ & 15.00 & 7.85 & & \\
\hline & Married & 1 & 16.06 & 10.33 & & \\
\hline & Widow & 7 & 17.82 & 7.46 & & \\
\hline \multirow{6}{*}{ Schooling } & Cannot read/write & 5 & 18.46 & 7.84 & \multirow{6}{*}{5,111} & \multirow{6}{*}{1.3} \\
\hline & $1^{\text {st }}-4^{\text {th }}$ grade & 5 & 16.63 & 8.41 & & \\
\hline & $5^{\text {th }}-6^{\text {th }}$ grade & 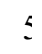 & 13.60 & 8.76 & & \\
\hline & $7^{\text {th }}-9^{\text {th }}$ grade & 2 & 7.00 & .00 & & \\
\hline & $10^{\text {th }}-12^{\text {th }}$ grade & 1 & 9.00 & & & \\
\hline & University level & 1 & 17.00 & & & \\
\hline \multirow{6}{*}{ Motive for admission } & Lived alone & 3 & 18.50 & 7.41 & \multirow{6}{*}{5,111} & \multirow{6}{*}{1.0} \\
\hline & $\begin{array}{l}\text { Difficulty in taking ca } \\
\text { himself }\end{array}$ & 3 & 15.92 & 7.49 & & \\
\hline & $\begin{array}{l}\text { Unavailability of the } \\
\text { children to provide sp } \\
\text { care }\end{array}$ & 1 & 16.80 & 9.43 & & \\
\hline & $\begin{array}{l}\text { The spouse needs spe } \\
\text { care }\end{array}$ & 1 & 17.07 & 9.21 & & \\
\hline & Without family/childr & 1 & 15.50 & 10.18 & & \\
\hline & $\begin{array}{l}\text { Preference for living } \mathrm{i} \\
\text { nursing home }\end{array}$ & 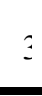 & 25.00 & 5.20 & & \\
\hline \multirow{4}{*}{ Institutionalization durati } & 1 Month - 6 Months & 1 & 17.88 & 9.95 & \multirow{4}{*}{3,113} & \multirow{4}{*}{2.6} \\
\hline & 7 Months - 1 Year & 2 & 15.92 & 7.67 & & \\
\hline & 2 Years - 10 Years & 6 & 18.70 & 7.44 & & \\
\hline & 11 Years - 20 Years & 1 & 12.82 & 8.35 & & \\
\hline
\end{tabular}

Note: ${ }^{*} p<0.05 ; * * p<0.01 ; * * * p<0.001$.

The results on satisfaction with overall social support (Total-SSSS) ranged from 44 to 75, with a mean value of 58.59 ( $S D=6.93)$. Thus, individuals present a high perceived satisfaction with overall social support (according to the criteria by Baptista et al., 2006). Regarding the factors individually, for 'satisfaction with friends' the mean was 20.63 ( $S D=2.98)$; concerning the factor 'intimacy', the mean level was $14.95(S D=2.73)$; for 'satisfaction with family' the average rate was $13.78(S D=1.52)$; and finally for the factor 'social activities' the mean level was $9.23(S D=2.75)$.

Concerning the SSSS mean values, a statistically significant difference $(t(115)=2.46, p=.02)$ was found between genders, indicating that the older women have a higher level of social support $(M=59.49 ; S D=6.01)$ than elderly men $(M=55.97 ; S D=8.68)$. The same was true with regard to the satisfaction with friends $(t(115)=-2.85, p=.005)$, in which older women presented significantly higher values $(M=21.08, S D=2.66)$ than elderly men $(M=19.33 ; S D=3.52)$. Moreover, no statistically significant differences between genders were observed regarding satisfaction with family $(t(115)=-1.45, p=.15)$. 
However, when comparing the mean levels of satisfaction with social support, between different age groups, no statistically significant differences were found for the total scale $(t(115)=.96, p=.34)$, for satisfaction with friends $(t(115)=.93, p=.35)$, or satisfaction with the family $(t(115)=.23, p=.82)$. The comparison of satisfaction with social support, between individuals who took and did not take initiative to go to a nursing home, presented no statistically significant differences for: the total scale $(t(115)=1.63, p=.11)$, the satisfaction with the friends $(t(115)=1.20, \mathrm{p}=.23)$, or the satisfaction with the family $(t(115)=1.84, p=.07)$ (see Table 4).

Table 4

Results for the comparison of the mean satisfaction with social support and gender, age, and initiative in admission $(N=117)$

\begin{tabular}{|c|c|c|c|c|c|c|}
\hline & & $\mathrm{N}$ & $M$ & $S D$ & $D f$ & $t$ \\
\hline \multicolumn{7}{|l|}{ Total - SSSS } \\
\hline Gender & $\begin{array}{l}\text { Male } \\
\text { Female }\end{array}$ & $\begin{array}{l}30 \\
87 \\
\end{array}$ & $\begin{array}{l}55.97 \\
59.49\end{array}$ & $\begin{array}{l}8.68 \\
6.01 \\
\end{array}$ & 115 & $-2.46^{*}$ \\
\hline \multicolumn{7}{|l|}{ Satisfaction with friends } \\
\hline \multirow{2}{*}{ Gender } & Male & 30 & 19.33 & 3.52 & \multirow{2}{*}{115} & \multirow{2}{*}{$-2.85^{*}$} \\
\hline & Female & 87 & 21.08 & 2.66 & & \\
\hline \multicolumn{7}{|l|}{ Satisfaction with family } \\
\hline \multirow{2}{*}{ Gender } & Male & $3 C$ & 13.43 & 1.72 & \multirow{2}{*}{115} & \multirow{2}{*}{-1.45} \\
\hline & Female & 87 & 13.90 & 1.43 & & \\
\hline \multicolumn{7}{|l|}{ Total - SSSS } \\
\hline \multirow{2}{*}{ Age } & $65-74$ years & 20 & 59.95 & 7.33 & \multirow{2}{*}{115} & \multirow{2}{*}{.96} \\
\hline & 75- 101 year: & 97 & 58.31 & 6.85 & & \\
\hline \multicolumn{7}{|l|}{ Satisfaction with friends } \\
\hline \multirow{2}{*}{ Age } & $65-74$ years & 20 & 21.20 & 2.88 & \multirow{2}{*}{115} & \multirow{2}{*}{.93} \\
\hline & 75-101 year: & 97 & 20.52 & 3.01 & & \\
\hline \multicolumn{7}{|l|}{ Satisfaction with family } \\
\hline \multirow{2}{*}{ Age } & $65-74$ years & 20 & 13.85 & 1.63 & \multirow{2}{*}{115} & \multirow{2}{*}{.23} \\
\hline & 75- 101 year: & 97 & 13.76 & 1.50 & & \\
\hline \multicolumn{7}{|l|}{ Total - SSSS } \\
\hline \multirow{2}{*}{ Own initiative in admissior } & Yes & 58 & 59.64 & 7.39 & \multirow{2}{*}{115} & \multirow{2}{*}{1.63} \\
\hline & No & 59 & 57.56 & 6.34 & & \\
\hline \multicolumn{7}{|l|}{ Satisfaction with friends } \\
\hline \multirow{2}{*}{ Own initiative in admissior } & Yes & 58 & 20.97 & 3.12 & \multirow{2}{*}{115} & \multirow{2}{*}{1.20} \\
\hline & No & 59 & 20.31 & 2.83 & & \\
\hline \multicolumn{7}{|l|}{ Satisfaction with family } \\
\hline Own initiative in admissior & Yes & 58 & 14.04 & 1.57 & 115 & 184 \\
\hline Own initiative in admissior & No & 59 & 13.53 & 1.43 & 115 & 1.84 \\
\hline
\end{tabular}

Moreover, the comparison of the satisfaction with social support between individuals with different marital statuses, were not statistically significant for the total scale $(F(3,113)=.05$, $p=.98)$, for the satisfaction with friends $(F(3,113)=.07, p=.97)$, or satisfaction with family $(F(3,113)=1.45, p=.23)$. Also, no statistically significant differences were found in the comparison between groups with different educational levels, for the total scale 
$(F(5,111)=.91, p=.48)$, for the satisfaction with friends $(F(5,111)=1.29, p=.27)$, or the satisfaction with family $(F(5,111)=1.79, p=.12)$ (see Table 5).

Table 5

Results for the comparison of the mean satisfaction with social support and marital status and schooling level $(N=117)$

\begin{tabular}{|c|c|c|c|c|c|c|}
\hline & & $\mathrm{N}$ & $M$ & $S D$ & $D f(B ; l$ & $F$ \\
\hline \multicolumn{7}{|l|}{ Total - SSSS } \\
\hline \multirow{4}{*}{ Marital Status } & Single & 23 & 58.35 & 5.50 & \multirow{4}{*}{3,113} & \multirow{4}{*}{.0} \\
\hline & Divorced & 6 & 58.33 & 6.77 & & \\
\hline & Married & 17 & 59.18 & 9.68 & & \\
\hline & Widow & 71 & 58.55 & 6.75 & & \\
\hline \multicolumn{7}{|c|}{ Satisfaction with friends } \\
\hline \multirow{4}{*}{ Marital Status } & Single & 23 & 20.48 & 2.33 & & \\
\hline & Divorced & 6 & 21.00 & 2.53 & \multirow{3}{*}{3,113} & \multirow{3}{*}{.07} \\
\hline & Married & 17 & 20.82 & 3.47 & & \\
\hline & Widow & 71 & 20.61 & 3.13 & & \\
\hline \multicolumn{7}{|c|}{ Satisfaction with family } \\
\hline \multirow{4}{*}{ Marital Status } & Single & 23 & 13.83 & 1.59 & \multirow{4}{*}{3,113} & \multirow{4}{*}{1.4} \\
\hline & Divorced & 6 & 13.50 & 2.51 & & \\
\hline & Married & 17 & 13.12 & 1.54 & & \\
\hline & Widow & 71 & 13.94 & 1.37 & & \\
\hline \multicolumn{7}{|l|}{ Total - SSSS } \\
\hline \multirow{6}{*}{ Schooling } & Cannot read/write & 57 & 58.91 & 7.94 & \multirow{6}{*}{5,111} & \multirow{6}{*}{.91} \\
\hline & $1^{\text {st }}-4^{\text {th }}$ grade & 51 & 58.55 & 5.38 & & \\
\hline & $5^{\text {th }}-6^{\text {th }}$ grade & 5 & 54.00 & 9.67 & & \\
\hline & $7^{\text {th }}-9^{\text {th }}$ grade & 2 & 62.00 & .00 & & \\
\hline & $10^{\text {th }}-12^{\text {th }}$ grade & 1 & 65.00 & & & \\
\hline & University level & 1 & 52.00 & & & \\
\hline \multicolumn{7}{|c|}{ Satisfaction with friends } \\
\hline \multirow{6}{*}{ Schooling } & Cannot read/write & 57 & 20.81 & 3.09 & \multirow{6}{*}{5,111} & \multirow{6}{*}{1.2} \\
\hline & $1^{\text {st }}-4^{\text {th }}$ grade & 51 & 20.53 & 2.75 & & \\
\hline & $5^{\text {th }}-6^{\text {th }}$ grade & 5 & 18.20 & 4.09 & & \\
\hline & $7^{\text {th }}-9^{\text {th }}$ grade & 2 & 24.00 & .00 & & \\
\hline & $10^{\text {th }}-12^{\text {th }}$ grade & 1 & 22.00 & & & \\
\hline & University level & 1 & 20.00 & & & \\
\hline \multicolumn{7}{|c|}{ Satisfaction with family } \\
\hline \multirow{6}{*}{ Schooling } & Cannot read/write & 57 & 13.68 & 1.45 & \multirow{6}{*}{5,111} & \multirow{6}{*}{1.7} \\
\hline & $1^{\text {st }}-4^{\text {th }}$ grade & 51 & 13.88 & 1.57 & & \\
\hline & $5^{\text {th }}-6^{\text {th }}$ grade & 5 & 14.20 & 1.10 & & \\
\hline & $7^{\text {th }}-9^{\text {th }}$ grade & 2 & 15.00 & .00 & & \\
\hline & $10^{\text {th }}-12^{\text {th }}$ grade & 1 & 13.00 & & & \\
\hline & University level & 1 & 10.00 & & & \\
\hline
\end{tabular}

As for the comparison of the satisfaction with social support, depending on the reason for admission at the nursing home, statistically significant differences were not observed for the total scale $(F(5,111)=1.59, p=.17)$, for satisfaction with friends $(F(5,111)=.48, p=.79)$, or for 
satisfaction with family $(F(5,111)=1.63, p=.16)$. In the same way, statistically significant differences were not observed when comparing satisfaction with social support among groups with different periods of institutionalization, for the total scale $(F(3,113)=1.82, p=.15)$, for satisfaction with friends $(F(3,113)=1.16, p=.33)$, or satisfaction with family $(F(3,113)=.98$, $p=.41$ ) (see Table 6).

Table 6

Results for the comparison of the mean satisfaction with social support and motive for admission and institutionalization duration $(N=117)$

\begin{tabular}{|c|c|c|c|c|c|c|}
\hline & & 1 & $M$ & $S D$ & $D f(B$ & $F$ \\
\hline \multicolumn{7}{|l|}{ Total - SSSS } \\
\hline \multirow{6}{*}{ Motive for admission } & Lived alone & 3 & 57.7 & 6.11 & \multirow{6}{*}{5,11} & \multirow{6}{*}{1.5} \\
\hline & $\begin{array}{l}\text { Difficulty in taking car } \\
\text { himself }\end{array}$ & 3 & 58.81 & 6.30 & & \\
\hline & $\begin{array}{l}\text { Unavailability of the } \\
\text { children to provide spe } \\
\text { care }\end{array}$ & 1 & 61.8 & 6.98 & & \\
\hline & $\begin{array}{l}\text { The spouse needs spec } \\
\text { care }\end{array}$ & 1 & $57.5^{\prime}$ & .20 & & \\
\hline & Without family/childre & 1 & 59.61 & 9.52 & & \\
\hline & $\begin{array}{l}\text { Preference for living ir } \\
\text { nursing home }\end{array}$ & $\therefore$ & 51.3 & 2.52 & & \\
\hline \multicolumn{7}{|l|}{ Satisfaction with friends } \\
\hline \multirow{6}{*}{ Motive for admission } & Lived alone & 3 & $20.4^{\prime}$ & 2.99 & \multirow{6}{*}{5,11} & \multirow{6}{*}{.48} \\
\hline & $\begin{array}{l}\text { Difficulty in taking car } \\
\text { himself }\end{array}$ & 3 & 20.6 & 2.85 & & \\
\hline & $\begin{array}{l}\text { Unavailability of the } \\
\text { children to provide spe } \\
\text { care }\end{array}$ & 1 & 20.9 & 2.40 & & \\
\hline & $\begin{array}{l}\text { The spouse needs spec } \\
\text { care }\end{array}$ & 1 & 20.4 & 3.46 & & \\
\hline & Without family/childre & 1 & 21.51 & 2.67 & & \\
\hline & $\begin{array}{l}\text { Preference for living ir } \\
\text { nursing home }\end{array}$ & $\therefore$ & 18.6 & 4.93 & & \\
\hline \multicolumn{7}{|l|}{ Satisfaction with family } \\
\hline \multirow{6}{*}{ Motive for admission } & Lived alone & 3 & 13.6 & 1.52 & \multirow{6}{*}{5,11} & \multirow{6}{*}{1.6} \\
\hline & $\begin{array}{l}\text { Difficulty in taking car } \\
\text { himself }\end{array}$ & 3 & 13.71 & 1.48 & & \\
\hline & $\begin{array}{l}\text { Unavailability of the } \\
\text { children to provide spe } \\
\text { care }\end{array}$ & 1 & 14.5: & 1.06 & & \\
\hline & $\begin{array}{l}\text { The spouse needs spec } \\
\text { care }\end{array}$ & 1 & 13.51 & 1.51 & & \\
\hline & Without family/childre & 1 & 13.21 & 2.10 & & \\
\hline & $\begin{array}{l}\text { Preference for living ir } \\
\text { nursing home }\end{array}$ & $\therefore$ & 15.01 & .00 & & \\
\hline \multicolumn{7}{|l|}{ Total - SSSS } \\
\hline Institutionalization durati & 1 Month - 6 Months & 1 & 57.3 & 6.39 & 3,11 & 1.8 \\
\hline
\end{tabular}




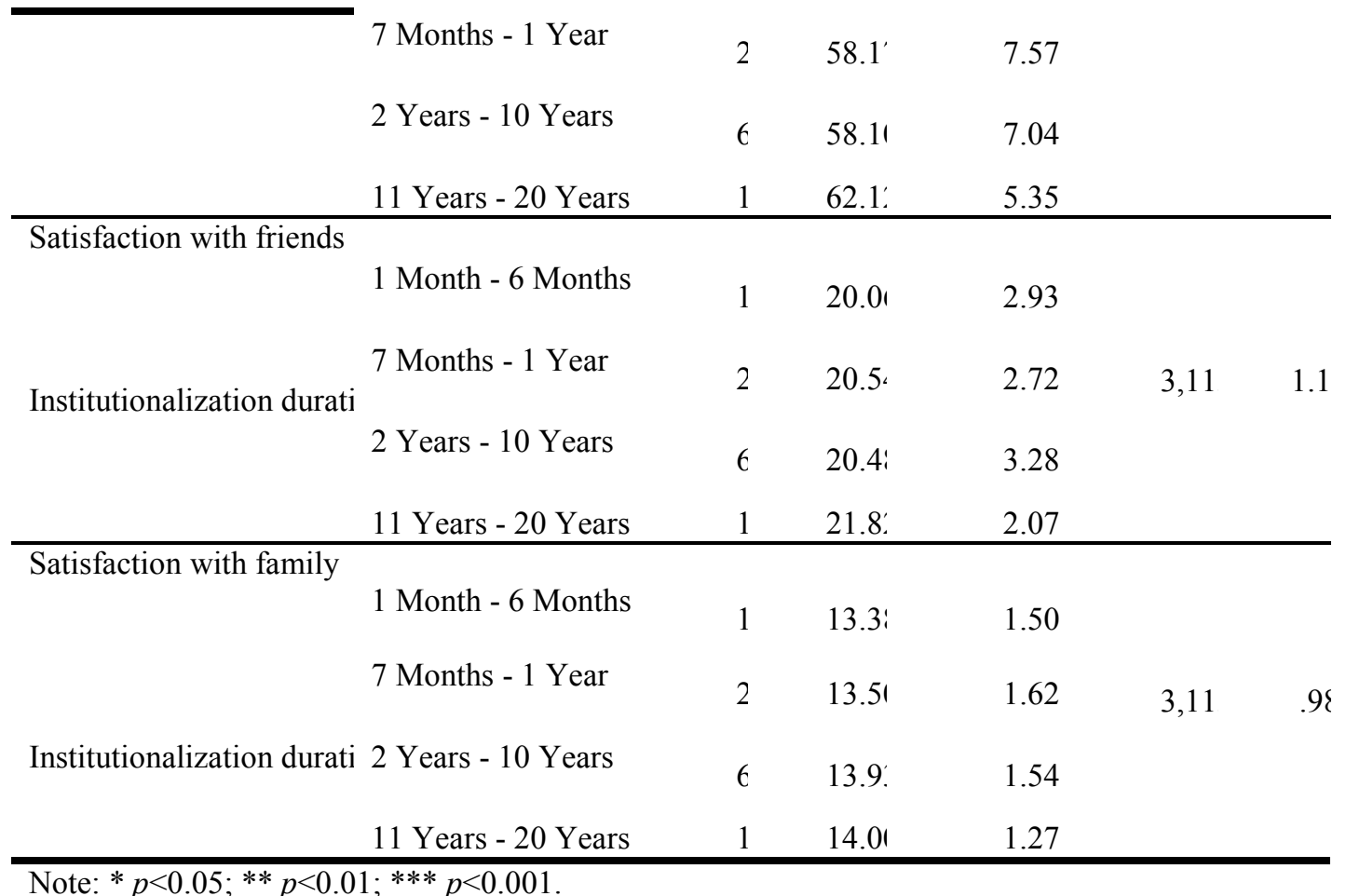

The correlation between depressive symptoms and social support was negative and statistically significant, despite being considered low $(r=-.36, p<.01)$ according to Cohen and Holliday's (1982) criteria. Thus, as the levels of geriatric depression rise, the satisfaction with social support tends to decrease. Regarding the association between the first SSSS factor, 'satisfaction with friends', and the GDS total score, there was a negative and statistically significant correlation, also considered low $(r=-.31, p=.001)$. The study of the relation between the third SSSS factor, 'satisfaction with family', and the total GDS score indicates no statistically significant correlation $(r=-.13, p=.171)$.

\section{DISCUSSION}

This study's results show that institutionalized elderly have a high rate of depressive symptoms (73.5\%), which corroborates results from other studies (e.g. Bergdahl, Allard, Alex Gustafson \& Lundman, 2007; Djernes, 2006; Gordilho, 2002; Irigaray \& Schneider, 2007; Stek et al., 2006). The very high incidence of geriatric depression found in this sample points to the need to make assessments in order to provide a better understanding, and to devise adequate means of intervention.

Regarding gender, the findings do not go in the same direction as other studies, which report a different incidence of depression between genders (e.g. Alvarado, Zunzunegui, Beland, Tellechea \& Sicotte, 2007; Gazalle et al. 2004; Papadopoulos et al. 2005; Santana \& Son, 2007; Sousa Medeiros, Moura Souza \& Moreira, 2007; Stek et al., 2006). Thus, gender, as a social and developmental dimension related to depression, ceases to be a possible explanatory factor in this group of institutionalized elderly. 
The educational levels did not influence the levels of geriatric depression in our study, which goes against previous studies that reported low schooling level as a risk factor for the development of depressive symptoms (e.g. Djernes, 2006, Papadopoulos et al. 2005; Stek et al., 2006).

With regard to the relation between geriatric depression and age, institutionalized elderly over 75 years old presented higher levels of depression than those younger than 74 years. This result corroborates those of other studies (e.g. Gazalle et al. 2004; Oliveira, 2005, Papadopoulos et al., 2005), in which age is considered a risk factor for the onset of depressive symptoms. These results may be related to the fact that, with advancing age, the elderly, particularly those in institutions, have less autonomy, less pleasant life experiences and more physical and sensory handicaps.

As for the marital status and geriatric depression, our data does not corroborate the results obtained by other authors (e.g. Djernes, 2006; Irigaray \& Schneider, 2007; Montorio \& Isal, 1999; Santana \& Son, 2007), which indicate that having a spouse or a person one can confide in, is related to a lower incidence of depressive symptoms. Furthermore, our data is not in agreement with the studies which argue that the elderly who do not have someone to confide in, or an intimate relationship, present a higher susceptibility for depressive symptoms (e.g. Chou \& Chi, 2005, Papadopoulos et al., 2005, Silva \& Sequeira, 2002; Stek et al., 2006). This result may be related to the fact that the intimate and marital relationships, in the context of institutionalization, often assume specificities and limitations related to the way these nursing homes work.

It is important to highlight that the elderly who were admitted to a nursing home on their own initiative, presented lower rates of depression than those who did not take the initiative to be admitted. This result corroborates Barenys' (1990) results, who reported that going to a nursing home is, for most of the elderly, strongly influenced by factors beyond their control and by a lack of alternatives, imposing as necessary and having possible implications for the development of depression. This result also suggests that the decision-making process regarding institutionalization, and the perceived autonomy in this process, may be important areas to intervene in order to prevent geriatric depression in elderly being institutionalized.

On the other hand, the institutionalization length does not seem to be a relevant factor for the presence, or absence, of geriatric depression in this study. This result is not in accordance with Shirley, Leung and Mak's, (2000) where the percentage of elderly patients with depressive symptoms is higher in recently institutionalized elderly In relation to the variable 'satisfaction with social support' indicate that the elderly after institutionalization, are satisfied with the relations established in the new context, however, they may also reflect some social desirability. As for satisfaction with the family, the results concur with the advocated by some authors (e.g. Juanola, Zamora, Rodríguez \& Hernández, 2005), that in this age group the family assumes an overriding importance, being one of the first sources of emotional support.

The results of this study indicate that older women have higher levels of satisfaction with social support than elderly men do. This result is in accordance with other studies (e.g., Gurung, Taylor and Seeman, 2003), which state that gender is often one of the greatest predictors of social support, and that women receive and give more life-long support, and experience benefits of that support from their social interactions. Likewise, there are 
statistically significant differences regarding satisfaction with friends, as did the results reported by Bell (1981), who states that older women have close friends and they care more about their friendships than men do. Furthermore, regarding social support, our data contradicts that presented by Caldas (2003, cited by Araújo et al., 2006), who considers that the best indicator for long-term institutionalization among the elderly is the lack of family support, i.e., the family's unavailability.

A correlation analysis between levels of geriatric depression and levels of satisfaction with the overall social support indicates that, as levels of depressive symptoms increase, satisfaction with social support decreases, which corroborates the arguments stating that the lower the social support, the higher the incidence of diseases or disorders in the elderly (Martins, 2005). Although the data suggests high levels of depressive symptoms, the sample also presents high levels of satisfaction with social support. Thus, our results do not corroborate those obtained by several authors showing that the lack of social support is the basis of depression in the elderly, namely in later-onset cases (e.g. Barg, Huss-Ashmore, Wittink, Murray, Bogner \& Gallo, 2006; Chen, Wei Hu, Qin, Copeland \& Hemingway, 2005; Djernes, 2006, Han, Kim, Lee, Pistulka \& Kim, 2007; Irigaray \& Schneider, 2007, Koizumi et al., 2005). The data also indicates a high level of satisfaction with family, followed by a high level of satisfaction with friends. The same was found in a study carried out by McKevitt et al. (2005), in which social support came primarily from family and friends.

Although, overall, the results indicate that the institutionalized elderly present high levels of depressive symptoms and high satisfaction with social support, the results indicate a negative correlation between these two dimensions. In this sense, the results suggest, that lower levels of satisfaction with social support may be associated with higher levels of depressive symptoms; thus, high levels of satisfaction with social support may somehow have a buffering effect on the development of depressive symptoms. In this way, social support seems to be a protective factor for depressive symptoms in the institutionalized elderly.

In this study, high levels of depressive symptoms stand out, which brings us to the importance of preventive and remedial action plans for this pathology. Studies suggest that the promotion of satisfaction with social support may be a dimension that ought to be developed/promoted, in order to make the elderly less vulnerable to the onset and progression of depressive symptoms. The psychosocial intervention strategies, to maintain and promote interpersonal and family relationships of the elderly, may be used simultaneously with other therapies, to promote the quality of life in institutionalized elderly. In this way, the promotion of relationships between the institutionalized elderly, with their community, friends and family, are part of an overall strategy to promote wellbeing, and to prevent depressive symptoms in the institutionalized elderly. Thus, an investment in the promotion of interpersonal relationships of institutionalized elderly may be a way of promoting life satisfaction, selfesteem, the ability to face problems, personal trust, as well as the desire to live and the quality of life of the elderly (Wolf \& Pereira, 2007, Robinson \& Wood, 2009).

\section{REFERENCES}


Abas, M., Hotopf, M., \& Prince, M. (2002). Depression and mortality in a high-risk population 11-Year follow-up of the Medical Research Council Elderly Hypertension Trial. British Journal of Psychiatry, 181, 123-128..

Alvarado, B. E., Zunzunegui, M. V., Béland, F., Sicotte, M., \& Tellechea, L. (2007). Social and Gender Inequalities in Depressive Symptoms Among Urban Older Adults of Latin America and the Caribbean. Journal of Gerontology, 62B, 226-237.

Araújo, S. S. C., Freire, D. B. L., Padilha, D. M. P., \& Baldisserotto, J. (2006). Suporte social, promoção de saúde e saúde bucal na população idosa no Brasil. Interface Comunicação, Saúde, Educação, 10, 203-216. doi:10.1590/S1414-32832006000100014

Balaswamy, S., Richardson, V., \& Price, C. (2004). Investigating Patterns of social Support Use by Widowers During Bereavement. The Journal of Men's Studies, 1, 67-84. doi:10.3149/jms.1301.67

Baptista, M. N., Morais, P. R., Rodrigues, T., \& Silva, J. A. C. (2006). Correlação entre sintomatologia depressiva e prática de actividades sociais em idosos. Avaliação Psicológica, 5, 77-85.

Barenys, M. P. (1990). Residencias de Ancianos - análisis sociológico. Barcelona: Fundació Caixa de Pensions.

Barg, F. K., Huss-Ashmore, R., Wittink, M. N., Murray, G. F., Bogner, H. R., \& Gallo, J. J. (2006). A Mixed-Methods Approach to Understanding Loneliness and Depression in Older Adults. Journal of Gerontology, 61B, 329-339. doi:10.1093/geronb/61.6.S329

Barreto, J. (2003). Escala de Depressão Geriátrica. In M. Guerreiro, C. Garcia, \& A. Mendonça, Escalas e testes na demência (pp. 60-61). Grupo de Estudos de Envelhecimento Cerebral e Demência.

Bell, R. (1981). Worlds of friendship. Beverly Hills: Sage.

Bergdahl, E., Allard, P., Alex, L., Lundman, B., \& Gustafson, Y. (2007). Gender differences in depression among the very old. International Psychogeriatrics, 19, 1125-1140. doi:10.1017/S1041610207005662

Blazer, D. (2000). Psychiatry and the oldest old. The American Journal of Psychiatry, 157, 1915-1924. doi:10.1176/appi.ajp.157.12.1915

Blazer, D. (2003). Depressão em idosos ( $3^{\mathrm{a}}$ Ed.). São Paulo: Editora Andrei.

Branch, L., \& Jette, A. (1982). A Prospective study of long-term care institutionalization among the aged. American Journal of public Health, 1373-1374. doi:10.2105/AJPH.72.12.1373

Brown, M., Lapane, K., \& Luisi, A. (2002). The management of depression in older nursing home residents. Journal of the American Geriatrics Society, 50(1), 69-76. doi:10.1046/j.1532-5415.2002.50010.x

Buil, P., \& Espino, J. (1999). Anciano y familia. Una relación en evolución. Anales Sis San Navarra, 22(1), 19-25.

Carrasco, M., Ortiz, L., \& Ballesteros, J. (2002). Envejecimiento y Psiquiatria Geriátrica en el siglo XXI. In L. Ortiz, M. Carrasco, \& J. Ballesteros (Eds.), Psiquiatria Geriátrica (pp. 3-14). Barcelona: Masson.

Carstensen, L. L. (1995). Motivação para o contato social ao longo do curso da vida: uma teoria de seletividade socioemocional. In A. L. Neri (Ed.), Psicologia do envelhecimento (pp.13-27). Campinas: Papirus.

Carvalho, V., \& Fernandez, M. (1999). Depressão no idoso. In M. Netto (Ed.), Gerontologia: A velhice e o envelhecimento em visão globalizada. São Paulo: Editora Atheneu. 
Ceinos, M. (2001). Depressión en ancianos: un problema de todos. Revista Cubana de Medicina. General Integral, 17(4), 316-320.

Chen, R., Wei, L., Hu, Z., Qin, X., Copeland, J., \& Hemingway, H. (2005). Depression in Older People in Rural China. Archives of Internal Medicine, 165, 2019-2025. doi:10.1001/archinte.165.17.2019

Chou, K., \& Chi, I. (2005). Prevalence and correlates of depression in Chinese oldest-old. Internacional Journal of Geriatric Psychiatry, 20, 41-50. doi:10.1002/gps.1246

Cohen, L. \& Holliday, M. (1982). Statistics for social scientists. London: Harper \&Row.

DeVellis, R. F. (1991). Scale development: Theory and applications. Newbury Prak: Sage Publications.

Diwan, S. (2008). Limited English Proficiency, Social Network. Characteristics, and Depressive Symptoms Among Older Immigrants. Journal of Gerontology, 63B, 184191. doi:10.1093/geronb/63.3.S184

Djernes, J. K. (2006). Prevalence and predictors of depression in populations of elderly: a review. Acta Psychiatrica Scandinavica, 113, 372-87. o. $\underline{0447.2006 .00770 . \mathrm{x}}$

Dunst, C., \& Trivette, C. (1990). Assessment of social support in early intervention programs. In S. Meisels, \& J. Shonkoff (Eds.), Handbook of early childhood intervention (pp. 326349). New York: Cambridge University Press.

Fernandes, P. (2002). A depressão no idoso. Coimbra: Quarteto Editora.

Figueiredo, D. (2007). Cuidados familiares ao idoso dependente. Lisboa: Climepsi Editores.

Fontaine, R. (2000). Psicologia do envelhecimento. Lisboa: Climepsi Editores.

Franch, V. (2002). Epidemiología de la depresión en el anciano. Informaciones psiquiátricas. Jornadas de actualizacion en Psicogeriatria, 167, 19-40.

Gallegos-Carrillo, K., Mudgal, J., Sánchez-García, S., Wagner, F., Gallo, J., Salmerón, J., \& Garcia-Peña, M. C. (2009). Social networks and health-related quality of life: a population based study among older adults. Salut Pública de México, 1, 6-13. doi:10.1590/S0036-36342009000100004

Garcia, A., Passos, A., Campo, A., Pinheiro, E., Barroso, F., Coutinho, ... Sholl-Franco, A. (2006). A depressão e o processo de envelhecimento. Ciências \& Cognição, 7, 111-121.

Gazalle, F., Lima, M. S., Tavares, B. F., \& Hallal, P. C. (2004). Sintomas depressivos e fatores associados em população idosa no Sul do Brasil. Revista de Saúde Pública, 38, 365-371. doi:10.1590/S0034-89102004000300005

Glass, T. A., Leon C. F. M., Bassuk, S. S., \& Berkman, L. F. (2006). Social engagement and depressive symptoms en late life longitudinal findings. Journal of Aging and Health, 18, 604-28. doi:10.1177/0898264306291017

Gordilho, A. (2002). Depressão, Ansiedade outros distúrbios afetivos e suicídio. In E. V. Freitas, L. Neri, A. L. Cançado, M. L. Gorzoni, \& S. M. Rocha (Orgs). Tratado de Geriatria e Gerontologia (pp. 204-15). Rio de Janeiro: Koogan.

Gurung, R. A. R., Taylor, S. E., \& Seeman, T. E. (2003). Accounting for changes in social support among married older adults: insights from the Mac Arthur studies of successful aging. Psychology and Aging, 18, 487-496. doi:10.1037/0882-7974.18.3.487

Han, H., Kim, M., Lee, H. B., Pistulka, G., \& Kim, K. B. (2007). Correlates of Depression in the Korean American Elderly: Focusing on Personal Resources of Social Support. Journal of Cross-Cultural Gerontology, 22, 115-127. doi:10.1007/s10823-006-9022-2 
Irigaray, T. Q., \& Schneider, R. H. (2007). Prevalência de depressão em idosas participantes da Universidade para a Terceira Idade. Revista de Psiquiatria do Ri Grande do Sul, 29, 19-27. doi:10.1590/S0101-81082007000100008

Juanola, M., Zamora, A., Rodríguez, M., \& Hernández, O. (2005). Influencia de algunas variables en las relaciones familiares del adulto mayor. Revista Cubana de Medicina General Integral, 21, 1-12.

Kendall, P. C., \& Warman, M. J. (1996). Emotional disorders in youth. In P. M. Salkovskis (Ed.), Frontiers of cognitive therapy (pp. 509-530). New York: The Guilford Press.

Koizumi, Y., Awata, S., Kuriyama, S., Ohmori, K., Hozawa, A., Seki, T., ... \& Tsuji, I. (2005). Association between social support and depression status in the elderly: Results of a 1 year community-based prospective cohort study in Japan. Psychiatry and Clinical Neurosciences, 59, 563-569. doi:10.1111/j.1440-1819.2005.01415.x

Lang, F. R., \& Carstensen, L. L. (1994). Close emotional relationships in late life: Further support for proactive aging in the social domain. Psychology and Aging, 9, 315-324. doi:10.1037/0882-7974.9.2.315

Lobo, A., \& Pereira, A. (2007). Idoso Institucionalizado: Funcionalidade e Aptidão Física. Revista Referência, 2, 61-68.

Lobo, A., Saz, P., Marcos, G., Día, J., \& De-la-Cámara, C. (1995). The prevalence of dementia and depression in the elderly community in a southern European population. The Zaragoza Study. Archives of General Psychiatry, 52, 497506. doi:10.1001/archpsyc.1995.03950180083011

Loureiro, M. (1999). Aspectos Psicológicos do Envelhecimento. In M. Loureiro (Org.), Envelhecer na Comunidade (pp. 7-17). Covilhã: Kreamus.

Mann, A. (2001). Depression in the elderly: findings from a community survey. Maturitas, 38, 53-59. doi:10.1016/S0378-5122(00)00191-2

Martín, F., Porto, M., \& Mellado, G. (2002). Instrumentos de evaluación y exploración complementaria. In L. A. Ortiz, M. M. Carrasco, \& J. C. Ballesteros (Eds.), Psiquiatria Geriátrica (pp. 123-169). Barcelona: Masson.

Martins, R. (2002). Envelhecimento demográfico. Millenium, 7, 121-126.

Martins, R. (2005). A relevância do apoio social na velhice. Millenium, 9, 128-134.

Mazza, M. M. P. R., \& Lefèvre, F. (2004). A instituição asilar segundo o cuidador familiar do idoso. Saúde e Sociedade, 13, 68-77. doi:10.1590/S0104-12902004000300008

McKevitt, C., Baldock, J., Hadlow, J., Moriarty, J., \& Butt, J. (2005). Identity, meaning and social support. In A. Walker (Ed.), Understanding Quality of Life in Old Age (pp.131145). Maidenhead: Open University Press.

Minicuci, N., Maggi, S., Pavan, M., Enzi, G., \& Crepaldi, G. (2002). Prevalence rate and correlates of depressive symptoms in older individuals: the Veneto Study. The Journals of Gerontology Series A: Biological Sciences and Medical Sciences, 57,155 161. doi:10.1093/gerona/57.3.M155

Ministério do Trabalho e da Solidariedade Social. (2001). Plano Avô. Lisboa: Ministério da Economia Instituto Português da Qualidade.

Montorio, I., \& Izal, M. (1999). Câmbios asociados al processo de envejecimiento. In M. Izal, \& I. Montorio (Eds.), Gerontología Conductal: Bases para la intervención y âmbitos de aplicación (pp. 33-66). Madrid: Editorial Síntesis.

Norton, M. C., Singh, A., Skoog, I., Corcoran, C., Tschanz, J. T., Zandi, P. P., ... Cache County Investigators. (2008). Church Attendance and New Episodes of Major 
Depression in a Community Study of Older Adults: The Cache County Study. Journal of Gerontology, 63B, 129-137. doi:10.1093/geronb/63.3.P129

Oliveira, J. (2005). Psicologia do Envelhecimento e do Idoso. Porto: Legis Editora.

Oliveira, K. L., Santos, A., Cruvinel, M., \& Néri, A. L. (2006). Relação entre ansiedade, depressão e desesperança entre grupos de idosos. Psicologia em Estudo, 11, 351-359. doi:10.1590/S1413-73722006000200014

Palarea, M. D. D., Pascual, B. M., \& Francés, F. C. (2002). Trastornos afectivos en el anciano. Revista Multidisciplinar de Gerontologia, 12, 19-25.

Papadopoulos, F., Petridou, S., Argyropoulou, V., Kontaxakis, V., Dessypris, N., \& Anastasiou, A. (2005). Prevalence and correlates of depression in late life: a population based study from a rural Greek town. International Journal of Geriatric Psychiatry, 20, 350-357. doi:10.1002/gps.1288

Paradela, E. M. P., Lourenço, R., \& Veras, R. (2005). Validação da Escala de Depressão Geriátrica num ambulatório geral. Revista de Saúde Pública, 39, 918-941. doi:10.1590/S0034-89102005000600008

Paúl, C. (1994). O papel das famílias na prestação de cuidados a crianças e idosos. In L. Almeida, \& I. Ribeiro (Orgs.), Família e Desenvolvimento (pp. 45-579). Portalegre: APPORT.

Paúl, C., \& Fonseca, A. M. (2001). Psicossociologia da Saúde. Lisboa: Climepsi.

Pedro, I. (2003). Salud mental en el anciano: identificación y cuidados de los principales transtornos. Madrid: Nueva Imprenta.

Porcu, M., Scantamburlo, V. M., Albrecht, N. R., Silva, S. P., Vallim, F. L., Araújo, C. R., ....Faiola, R.(2002). Estudo comparativo sobre a prevalência de sintomas depressivos em idosos hospitalizados, institucionalizados e residentes na comunidade. Acta Scientiarum, 24, 713-717.

Ramos, M. P. (2002). Apoio social e saúde entre Idosos. Sociologias, 4, 156-175. doi:10.1590/S1517-45222002000100007

Rasulo, D., Christensen, K., \& Tomasini, C. (2005). The influence of social relations on mortality in later life: a study on elderly Danish twins. The Gerontologist, 45, 601-608. doi:10.1590/S1517-45222002000100007

Ribeiro, J. L. P. (1999). Escala de Satisfação com o Suporte Social (ESSS). Análise Psicológica, 3(17), 547-558.

Rodrigues, V., \& Madeira, M. (2009). Suporte social e saúde mental: revisão da literatura. Revista da Faculdade de Ciências da Saúde, edições Universidade Fernando Pessoa, 6, 390-399.

Roth, S. (2000). Aspectos clínicos, biológicos y sociales de las depresiones en la Tercera Edad. Actas españolas de Psiquiatría, 28, 32-37.

Roure, R., Reig, A., \& Vida, J. (2002). Percepción de apoyo social en pacientes hospitalizados. Revista Multidisciplinar de Gerontologia, 12, 79-85.

Salovey, P., Detweiler, J. B., Steward, W. T., \& Rothman, A. J. (2000). Emotional states and physical health. American Psychologist, 55, 110-121. doi:10.1037//0003-066X.55.1.110

Sarason, I. G., Levine, H. M., Basham, R. B., \& Sarason, B. R. (1983). Assessing social support: the social support questionnaire. Journal of Personality and Social Psychology, 44, 127-139. doi:10.1037//0022-3514.44.1.127 
Scazufca, M., Menezes, P. R., \& Almeida, O. P. (2002). Caregiver burden in an elderly population with depression in São Paulo, Brazil. Soc Psychiatry Psychiatr Epidemiol, 37, 416-422. doi:10.1007/s00127-002-0571-6

Sequeira, A., \& Silva, M. (2002). O bem-estar da pessoa idosa no meio rural. Análise Psicológica, 3, 505-516.

Shirley, P., Leung, Y., \& Mak, W. (2000). Depression in Institutionalised older peolple with impaired vision. International Journal of Geriatric Psychiatry, 15, 1120-1124.

Siqueira, M. M. (2008). Construcção e validação da escala de percepção de suporte social. Psicologia em Estudo, 13(2), 381-388. doi:10.1590/S1413-73722008000200021

Skarsater, I., Langius, A., Agren, H., Haggstrom, L., \& Dencker, K. (2005). Sense of coherence and social support in relation to recovery in first-episode patients with major depression: A one-year prospective study. International Journal of Mental Health Nursing, 14, 258-264. doi:10.1111/j.1440-0979.2005.00390.x

Sousa, L., Figueiredo, D., \& Cerqueira, M. (2004). Envelhecer em Família: os cuidados familiares na velhice. Porto: Ambar.

Sousa, R. L., Medeiros, J. G. M., Moura, A. C. L., Souza, C. L. M., \& Moreira, I. F. (2007). Validity and reliability of the Geriatric Depression Scale for the identification of depressed patients in a general hospital. Jornal Brasileiro de Psiquiatria, 56, 78-82. doi:10.1590/S0047-20852007000200005

Spar, J., \& La Rue, A. (1998). Guia de psiquiatria geriátrica. Lisboa: Climepsi Editores.

Stek, M. L., Vinkers, D. J., Gussekloo, J., Van Der Mast, R. C., Beekman, A. T. F., \& Westendorp, R. G. J. (2006). Natural history of depression in the oldest old populationbased prospective study. British Journal of Psychiatry, 188, 65-69. doi:10.1192/bjp.188.1.65

Stella, F., Gobbi, S., Corazza, D. I., \& Costa, J. L. R. (2002). Depressão no Idoso: Diagnóstico, Tratamento e Benefícios da Atividade Física. Motriz, 8, 91-98.

Strain, L., Philip, D., \& Blandford, A. (2006). Depressive symptoms among older adults in urban and rural áreas. Internacional Journal of Geriatric Psychiatry, 21, 1175-1180.

Vaz Serra, A. (1999). O Stress na Vida de Todos os Dias. Coimbra.

Veríssimo, M. T. (2006). Avaliação multidimensional do Idoso. Lisboa: Editora Psiquiatria Clínica.

Vieira, E. (1996). Manual de gerontologia: um guia teórico prático para profissionais, cuidadores e familiares. Rio de Janeiro: Editora Revinter.

Yesavage, Y. G., Brink, T. L., Rose, T. L., Lum, O., Huang, V., Adey, M. B., \& Leirer, V. O. (1983). Development and validation of a geriatric depression screening scale: A preliminary report. Journal of Psychiatric Research, 17, 37-49. doi:10.1016/0022$\underline{3956(82) 90033-4}$

\section{Acknowledgements:}

The authors would like to thank the availability of the institutions were the data was collected. 